by James B. Jagol, James G. Gehling ${ }^{2}$, John R. Paterson ${ }^{3}$, Glenn A. Brock ${ }^{4}$ and Wenlong Zang ${ }^{5}$

\title{
Cambrian stratigraphy and biostratigraphy of the Flinders Ranges and the north coast of Kangaroo Island, South Australia
}

\author{
${ }^{1}$ School of Natural and Built Environments, University of South Australia, Mawson Lakes, SA 5095, Australia. E-mail: jim.jago@unisa.edu.au \\ ${ }^{2}$ South Australian Museum, North Terrace, Adelaide, SA 5000, Australia. E-mail: jim.gehling@ samuseum.sa.gov.au \\ ${ }^{3}$ Division of Earth Sciences, School of Environmental and Rural Science, University of New England, Armidale, NSW 2351, Australia. Email: \\ jpater20@une.edu.au \\ ${ }^{4}$ Department of Biological Sciences, Macquarie University, NSW 2109, Australia. E-mail: glenn.brock@mq.edu.au \\ ${ }^{5}$ Oroya Mining Ltd, Suite 3, 72 Canning Highway, Victoria Park, WA 6100, Australia. E-mail: WZang@strategicenergy.com.au
}

The lower Cambrian sediments of the Flinders Ranges, South Australia can be divided into three sequence sets. They rest unconformably on the Ediacaran succession. Sequence set $\epsilon 1$ comprises lower clastic units overlain by a carbonate dominated marine succession that shows marked lateral and vertical facies changes. Sequence sets $E 2$ and 63 together comprise a largely clastic dominated succession of marginal marine to nonmarine sediments with subordinate shallow marine carbonates. Sequence set $\epsilon 1$ is richly fossiliferous at some levels with biostratigraphy established for trilobites, archaeocyaths, brachiopods, small shelly fossils, acritarchs and molluscs. The Eти Bay Shale Lagerstätte (Cambrian Series 2) from the north coast of Kangaroo Island occurs within a clastic-rich shelf succession dominated by conglomerate and sandstone. The fossil content is dominated by trilobites in terms of relative abundance and currently over 50 taxa are known including, Anomalocaris, the bivalved arthropods Isoxys and Tuzoia, the nektaspids Emucaris and Kangacaris, the megacheiran Oestokerkus amongst a variety of other arthropods. Other common taxa include palaeoscolecid worms, Myoscolex, sponges, hyoliths, brachiopods, a vetulicolian and several other enigmatic forms. The oldest known well preserved complex arthropod eyes occur in this biota.

During the Cambrian, Australia was near the equator and in the tropical carbonate development zone (Brock et al., 2000, Jago et al., 2006). In South Australia, Cambrian sediments occur in the Stansbury, Arrowie, Warburton and eastern Officer basins (Figure 1). In the Stansbury and Arrowie basins, Cambrian sediments rest unconformably on Neoproterozoic rocks, probably reflecting the influence of the late Ediacaran Petermann Orogeny of Central Australia. Cambrian deposition was strongly influenced by regional tectonism, starting with rifting and finishing with the 514-490 Ma Delamerian Orogeny. The following information is based on Zang et al., (2004, 2006). More detailed descriptions and interpretation of individual stratigraphic units are found in Gravestock (1995). Figure 2 summarises the Cambrian stratigraphic relationships of the Arrowie and Stansbury basins. The Cambrian of the $\mathrm{N}$ coast of Kangaroo Island is treated separately.

\section{Cambrian succession in the Arrowie Basin}

Gravestock (1995) divided the Cambrian of South Australia into four sequence sets, $\epsilon 1, \epsilon 2, \epsilon 3$ and $\epsilon 4$. Set $€ 4$, from the Warburton Basin, is not considered herein. The lowest Cambrian sequence, $E 1.0$, Uratanna Formation, has limited outcrop in the northern Flinders Ranges. It comprises channel deposits overlain by prodeltaic and deltaic siltstones and sandstones and was deposited in valleys cut into the Ediacaran Rawnsley Quartzite. Where the Uratanna Formation is absent, the Parachilna Formation disconformably overlies the Rawnsley Quartzite (Gravestock, 1995); where both the Uratanna and the Parachilna Formations are missing, the younger Hawker Group carbonates directly overlie the Ediacaran sediments. Mount and McDonald (1992) suggested that the change from the clastic dominated Ediacaran, Uratanna and Parachilna successions indicated a decrease in clastic sediment supply due to drowning of source areas in central and southern Australia.

Sequence 61.1 (Parachilna Formation, Woodendinna Dolomite, lower Wilkawillina Limestone) contains an unconformity that divides the sequence into subsequences $\mathrm{E} 1.1 \mathrm{~A}$ and $\mathrm{E} 1.1 \mathrm{~B}$; the unconformity does not extend beyond the shelf edge. The Parachilna Formation comprises transgressive upwards fining sandstones and siltstones with minor carbonates. The basal sandstones are strongly bioturbated with abundant Diplocraterion in places. The maximum of this initial Cambrian transgression was reached at the top of $\in 1.1 \mathrm{~A}$ (c. Tommotian) with deposition of the Woodendinna Dolomite that comprises oolitic, stromatolitic, dolomitic shale with desiccation 


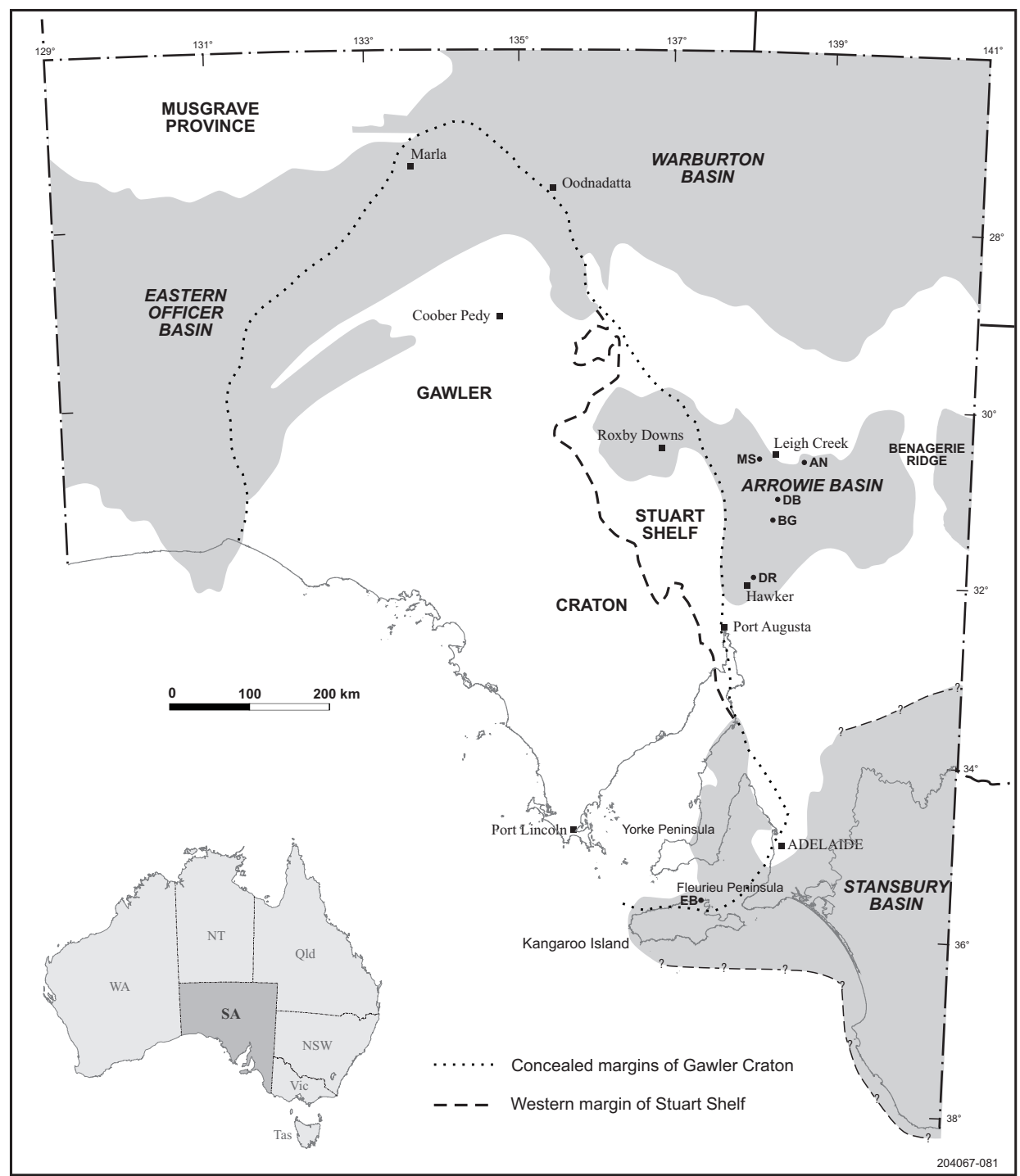

Figure 1 Cambrian basins of South Australia (after Jago et al., 2006). AN, Angepena-Nepabunna area; BG, Bunkers Graben; DB, Donkey Bore Syncline; DR, Druid Range; EB, Emu Bay; MS, Mt Scott Range.

cracks and halite casts plus abundant quartz sand horizons (Haslett, 1975). Sequence E1.1B commences with the lower Wilkawillina Limestone representing an Atdabanian shelf limestone that shows marked lateral facies changes and passes basinwards (eastwards) into the Wirrapowie Limestone which contains the oldest known archaeocyaths and trilobites in Australia. On shelf areas, the Woodendinna Dolomite is overlain disconformably by the lower Wilkawillina Limestone; basinwards there is no corresponding break within the Wirrapowie Limestone.

Sequences $E 1.1$ and $E 1.2$ are separated by the Flinders Unconformity (James and Gravestock, 1990) with the lower Wilkawillina Limestone disconformably overlain by either the middle Wilkawillina Limestone (platform carbonates) or the Mernmerna Formation (dark slope facies carbonates and calcareous siltstones). There are numerous lateral and vertical facies changes (Daily, 1976). The limestone shows considerable thickness variations with $100-500 \mathrm{~m}$ in many sections, up to $800 \mathrm{~m}$ in the Bunkers Graben (Clark, 1990) and over 2,500 $\mathrm{m}$ in the Nepabunna Trough (Gravestock, 1995). In the northern Flinders Ranges, in the AngepenaNepabunna area, there are two siltstone units (Midwerta Shale,
Nepabunna Siltstone) that intertongue with limestones of the Mernmerna Formation.

Sequence $€ 1.3$ commences with the Bunkers Sandstone, which in the Bunkers Graben comprises up to $300 \mathrm{~m}$ of cross bedded, quartz sandstone, but elsewhere it is mainly either quite thin or missing; however, in the Donkey Bore Syncline, to the NE, it comprises deeper water basin floor fan deposits (Reilly and Lang, 2003). The distinctive khaki Oraparinna Shale represents a transgressive unit; in the eastern Nepabunna Trough the Oraparinna Shale intertongues with fine to medium grained feldspathic sandstones of the Narina Greywacke (Gravestock, 1995). In places, the Oraparinna Shale abuts reef complexes of the upper Wilkawillina Limestone (Clark, 1990). The dark silty limestones of the upper Mernmerna Formation comprise the main transgressive unit beyond the shelf edge. The upper Wilkawillina Limestone and the Moorowie Formation both contain archaeocyath-rich reef and biohermal complexes. These include some of the earliest known corals (e.g., Fuller and Jenkins, 2007) and were deposited during the worldwide Botoman transgression (Gravestock and Shergold, 2001).

Above the Hawker Group in the Flinders Ranges there is much less lateral and vertical lithological variation. Sequence 62 was deposited during the world wide Toyonian regression (Gravestock and Shergold, 2001); it comprises the dominantly iron-rich red Billy Creek Formation deltaic sandstones and siltstones (Moore, 1980) and the overlying shallow marine carbonates of the Wirrealpa Limestone (Youngs, 1977). In the Mt Scott Range area, the Aroona Creek Limestone is equivalent to the Wirrealpa Limestone.

Gravestock (1995) suggested that Sequence E3 comprises the clastic dominated Lake Frome Group, although it could be argued that sequences $€ 2$ and $€ 3$ are a single clastic dominated succession briefly interrupted by the Wirrealpa Limestone. The lowest member of the Lake Frome Group is the Moodlatana Formation that comprises marginal marine shale, siltstone (including evaporite casts and abundant trace fossils) and cross bedded sandstones with two or three thin carbonate units near the top, one of which contains the youngest known Cambrian trilobites in the Flinders Ranges. The conformably overlying Balcoracana Formation comprises a shallow to marginal marine cyclic succession of shallowing upwards packages of red mudstones with abundant trilobite tracks that pass up into thin horizons of stromatolitic carbonates. The Pantapinna Sandstone comprises mainly planar to trough cross bedded fine to medium grained sandstones with minor siltstone and shale; much of the Pantapinna is probably of marginal marine to fluvial origin, 
although there is some open marine influence. The Grindstone Range Formation has a shallow marine lower part comprising well bedded fine sandstone with abundant planar cross bedding. The upper half, the Dawson Hill Member, is a fine to medium grained sandstone with abundant tabular cross bedding; it has numerous pebble and cobble clast horizons (Jago et al., 2010). Gravestock (1995) suggested a fluvial sandy braidplain depositional environment. The top of the Grindstone Range Formation is not exposed.

\section{Cambrian biostratigraphy of the Stansbury and Arrowie Basins}

The Cambrian biostratigraphy of South Australia has formed the basis of early Cambrian correlations between Australia and elsewhere (Gravestock, 1984; Jell in Bengtson et al., 1990; Zhuravlev and Gravestock, 1994; Paterson and Brock, 2007). Summaries are found in Gravestock et al. (2001), Jago et al. (2006) and Kruse et al. (2009). In the Arrowie and Stansbury basins, fossils occur mainly in the lower part of the succession, i.e., Hawker Group and correlates. Jell in Bengtson et al. (1990) erected four trilobite zones: Abadiella huoi (base), Pararaia tatei, P. bunyerooensis and P. janeae Zones (Figure 2). Paterson and Brock (2007) correlated the A. huoi Zone with the Chinese Parabadiella Zone and with the latest Atdabanian-earliest Botoman in Siberia.

The Pararaia tatei Zone correlates with the EoredlichiaWutingaspis Zone of China and the early Botoman Bergeroniellus micmacciformis-Erbiella Zone of Siberia (Jell in Bengtson et al., 1990, Paterson and Brock, 2007). Paterson and Brock (2007) correlated the P. bunyerooensis Zone with the Yunnanocephalus assemblage subzone (upper Eoredlichia-Wutingaspis Zone) of South China. The Pararaia janeae Zone contains the most trilobite taxa; Paterson and Brock (2007) suggested correlation with the Tsanglangpuan Stage of China and the Bergeroniellus gurarii to Bergeroniaspis ornata Zones (Botoman) of Siberia.

Higher in the succession in the Flinders Ranges (Arrowie Basin), trilobites are known from only three stratigraphic levels. The emuellid, Balcoracania dailyi, occurs in gregarious clusters in the Billy Creek Formation (Paterson et al., 2007a). This is probably late Botoman and may correlate with the Emu Bay Shale and Marsden Sandstone from Kangaroo Island (see below). Redlichia guizhouensis and Onaraspis rubra occur in the Wirrealpa Limestone and Moodlatana Formation, respectively; these last two formations have been correlated with the late early Cambrian Lungwangmiaoan Stage of China (Jell in Bengtson et al., 1990), or the latest Toyonian of Siberia (Paterson and Brock 2007).

The shallow water carbonates of the Arrowie and Stansbury basins contain abundant archaeocyaths. Gravestock (1984) and Zhuravlev and Gravestock (1994) recognised three Atdabanian archaeocyath zones from the Wilkawillina Limestone beneath the Flinders Unconformity, Warriootacyathus wilkawillensis (base), Spirillicyathus tenuis and Jugalicyathus tardus Zones (Figure 2). The informal term Syringocnema favus beds was erected by Zhuravlev and Gravestock (1994) for the abundant assemblage of archaeocyaths and radiocyaths that occurs in both the Arrowie and Stansbury basins within the Wilkawillina Limestone and correlates above the Flinders Unconformity. Paterson et al. (2007b) suggested that the archaeocyathan fauna referred to as the 'Syringocnema favus beds' is early Botoman (pre-Pararaia janeae Zone) in age. Kruse (1991) reported the youngest known archaeocyath fauna in Australia from the Wirrealpa Limestone.

Four informal brachiopod assemblages are recognized (Jago et al., 2006). The oldest assemblage, dominated by a new species of Askepasma, is mid-Atdabanian in age from the basal Wilkawillina Limestone and Wirrapowie Limestone of the Arrowie Basin. Undescribed calciate taxa from the lower Wirrapowie Limestone cooccur with this paterinid taxon. The succeeding Eoobolus aff viridis Assemblage Zone, first erected by Gravestock et al. (2001), ranges from late Atdabanian to mid Botoman in both the Arrowie and Stansbury basins; the most abundant taxon in this zone is Kyrshabaktella davidi. The overlying Eoobolus priscus Assemblage Zone is latest Botoman and occurs within the upper Parara Limestone in the Stansbury Basin and the upper Mernmerna Formation in the Arrowie Basin. The youngest brachiopod zone is the Vandalotreta djagoran Assemblage Zone which is characterised by the acrotretid Vandalotreta djagoran in both the Arrowie and Stansbury basins, plus the obolellid Trematobolus wirrialpensis in the Toyonian Wirrealpa Limestone.

There is a diverse and relatively common molluscan fauna in the early Cambrian carbonate successions of the Arrowie and Stansbury basins. Gravestock et al. (2001) erected four informal molluscan assemblages: the Pelagiella subangulata (base), Bemella communis, Stenotheca drepanoida and Pelagiella madianensis "zones".

Topper et al. (2011) described the oldest bradoriid fauna in Australia from the Ajax and Wirrapowie limestones of the Flinders Ranges. The oldest bradoriid occurs c. $20 \mathrm{~m}$ below the first appearance of Abadiella huoi. Skovsted et al. (2006) and Topper et al. (2007, 2011) described biostratigraphically significant bradoriid assemblages correlating with each of the younger (post A. huoi) trilobite zones noted above.

Abundant small shelly fossils (SSF) within the carbonate units of the Stansbury and Arrowie basins have been documented by Bischoff (1976), Bengtson et al. (1990), Brock and Cooper (1993), Gravestock et al. (2001), Skovsted et al. (2008, 2009 a, b, 2011) and Topper et al. (2009). Skovsted et al. (2011) demonstrated a consistent biostratigraphic disjunct between the tommotiid Eccentrotheca helenia and isolated sclerites of Kulparina rostrata and "Eccentrotheca" guano. Eccentrotheca helenia occurs in the Ajax and Wilkawillina Limestones with a stratigraphic range coincident with Abadiella huoi. In contrast, the stratigraphic ranges of $K$. rostrata and ' $E$.' guano are largely coeval, with the LAD of both sclerite types occurring significantly below the FAD of A. huoi and E. helenia. Gravestock et al. (2001) erected three informal SSF assemblage zones: Hippopharangites dailyi (base), Australohalkieria parva and Kaimenella reticulata, although the utility of these zones remains to be tested outside the Stansbury Basin.

Seven acritarch assemblage zones have been reported from the Lower Cambrian of the Arrowie and Stansbury basins (Zang et al., 2004, 2007). These extend from near the Ediacaran-Cambrian boundary within the Uratanna Formation to the Toyonian. Details are given by Zang et al. (2007).

\section{Cambrian stratigraphy of the north coast of Kangaroo Island}

Flöttmann et al. (1998) suggested that the Cambrian successions on Kangaroo Island comprise essentially unmetamorphosed shelf 


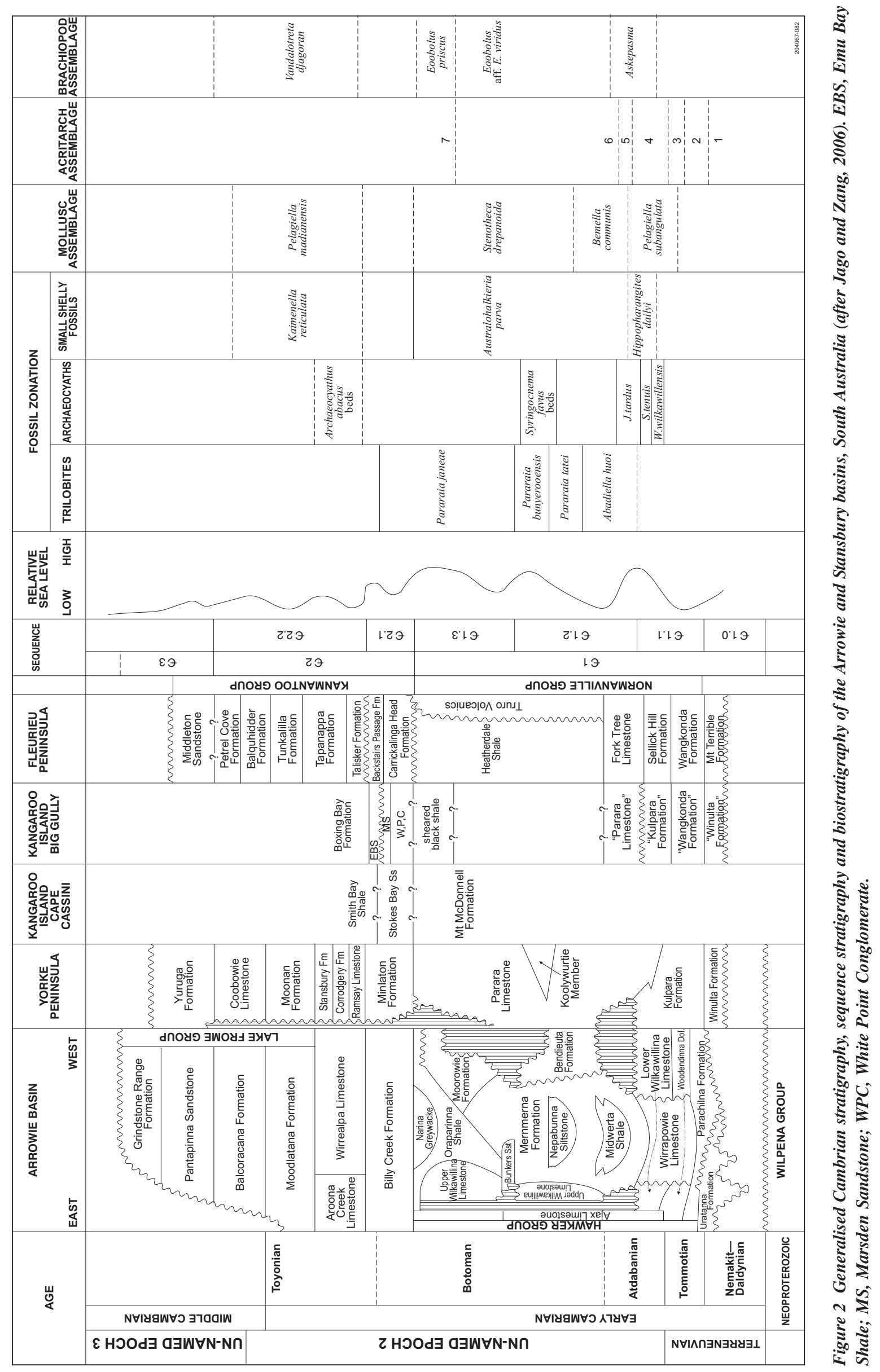



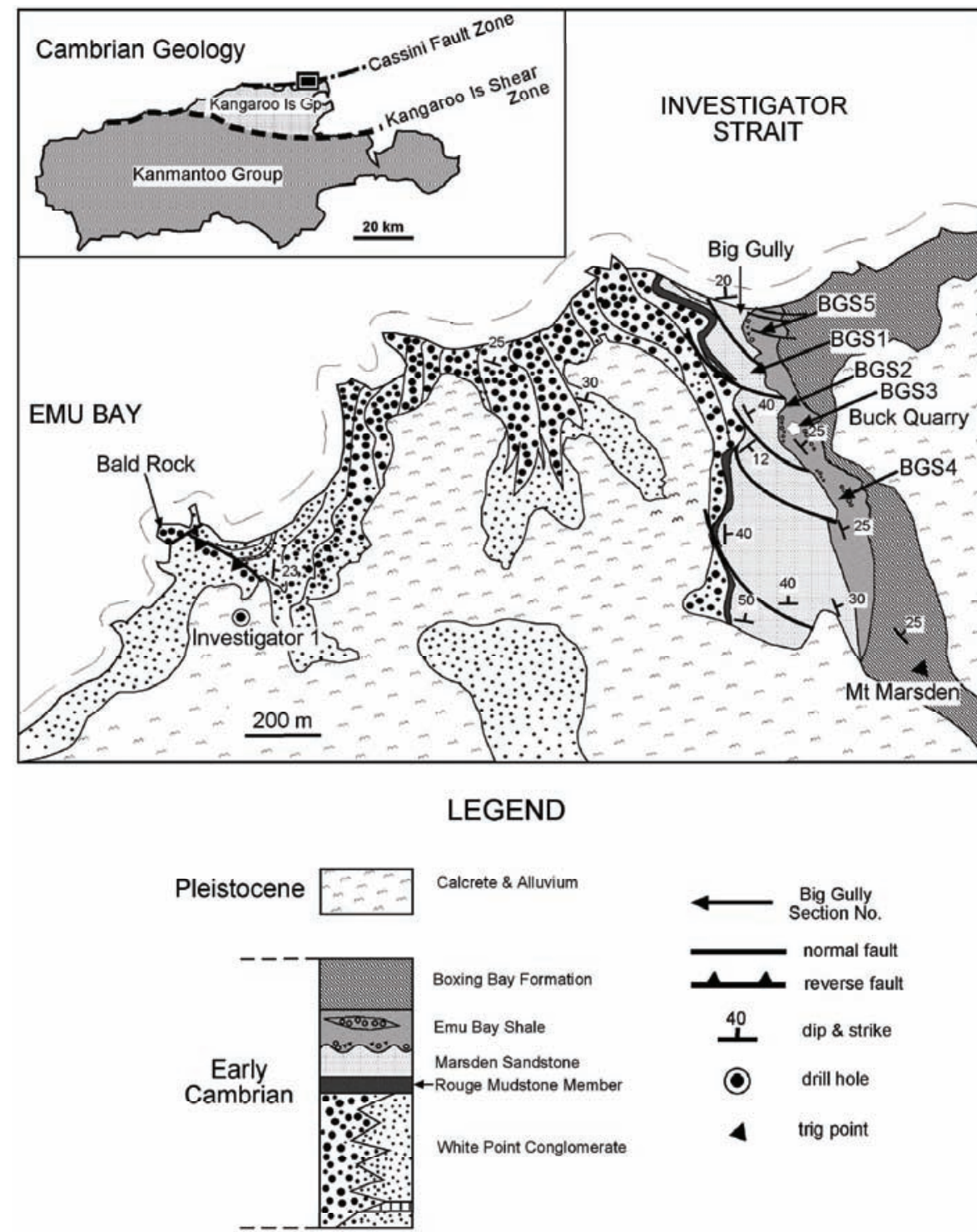

Figure 3 Geological map of the Big Gully area, $N$ coast of Kangaroo Island (from Gehling et al., 2011). BGS, Big Gully Section.

sediments, the Kangaroo Island Group (Daily, 1956), to the $\mathrm{N}$ of the Kangaroo Island Shear Zone (Figure 3) and the thick metamorphosed turbidite dominated Kanmantoo Group deposits to the S. Daily et al. (1979) considered that on the $\mathrm{N}$ coast of Kangaroo Island, the Kangaroo Island Group comprised six formations: Mt McDonnell Formation (base, containing Botoman archaeocyaths), Stokes Bay Sandstone, Smith Bay Shale, White Point Conglomerate, Emu Bay Shale (containing the Emu Bay Shale Lagerstätte) and Boxing Bay Formation. The top of the succession is not exposed. The three lowest formations outcrop between Smith Bay and Snelling Beach to the W of Emu Bay; from Emu Bay to the E the top three formations outcrop between Cape D'Estaing and Point Marsden, with the only suggested link being the Smith Bay Shale reported by Daily et al. (1980) at the base of a measured section that continues up through the White Point Conglomerate, Emu Bay Shale and Boxing Bay Formation. Gehling et al. (2011) regarded the "eastern" Smith Bay Shale of Daily et al. (1980) as part of the White Point Conglomerate and thus there is no proven link between the two areas of Cambrian sediments along the N coast of Kangaroo Island. Gehling et al. (2011) separated out the top part of the White Point Conglomerate as described by Daily et al. (1980) as a new formation, the Marsden Sandstone, which includes the thin Rouge Mudstone Member at the base. Stratigraphic correlation of the Cambrian units on the $\mathrm{N}$ coast of Kangaroo Island with those on Yorke and Fleurieu peninsulas is shown in Figure 2.

Gehling et al. (2011) noted that the tectonosedimentary setting of the Cambrian successions to the $\mathrm{N}$ of the Kangaroo Island Shear Zone is unclear. Nedin (1995b) suggested that the Kangaroo Island Group may have been deposited in a series of sub-basins in the area of syndepositional tectonic activity. This tectonic activity is what Daily and Forbes (1969) termed the Kangarooian Movements and may represent an early phase of the Delamerian Orogeny, the timing of which is discussed by Foden et al. (2006).

\section{Geology in the vicinity of the Emu Bay Shale Lagerstätte}

Gehling et al. (2011) mapped the area around the known occurrences of the Emu Bay Shale Lagerstätte (Figure 3). The lowest unit is the White Point Conglomerate that, in coastal sections, comprises cobble to boulder polymict conglomerate with subordinate sandstone and mudstone horizons. Clast types include archaeocyath-bearing limestones, dolomites, granite, gneiss and quartzite, all consistent with having been derived from the Proterozoic and Cambrian rocks of Yorke Peninsula to the N. The clast size decreases rapidly to the $\mathrm{S}$ with the conglomerate horizons becoming lenticular and disappearing entirely about $400 \mathrm{~m} \mathrm{~S}$ of the coast. The White Point Conglomerate is overlain by the Marsden Sandstone which is essentially a fine to medium-grained feldspathic sandstone at the base of which is the Rouge Mudstone Member that comprises $3 \mathrm{~m}$ of bioturbated argillaceous limestone containing the emuellid trilobite Balcoracania dailyi. The Marsden Sandstone is overlain unconformably by the Emu Bay Shale (Gehling et al., 2011). Detailed mapping of the area indicates that there was considerable syndepositional folding and faulting during deposition of the White Point Conglomerate and the Marsden Sandstone (Figures 3 and 4).

The Emu Bay Shale comprises dark grey to black laminated mudstone, with subordinate lenticular cross bedded fine sandstone beds with at least one conglomerate horizon with a clast content similar to that found in the White Point Conglomerate. The mudstone containing the Lagerstätte is not bioturbated. The water column above the sediment-water interface was oxic while the sediment below the sediment-water interface was anoxic with a cyanobacterial mat at the interface playing an important part in the preservation of the Lagerstätte (McKirdy et al., 2011; Hall et al., 2011). The Emu Bay Shale coarsens upwards with large arthropod tracks including 
NORTH COAST

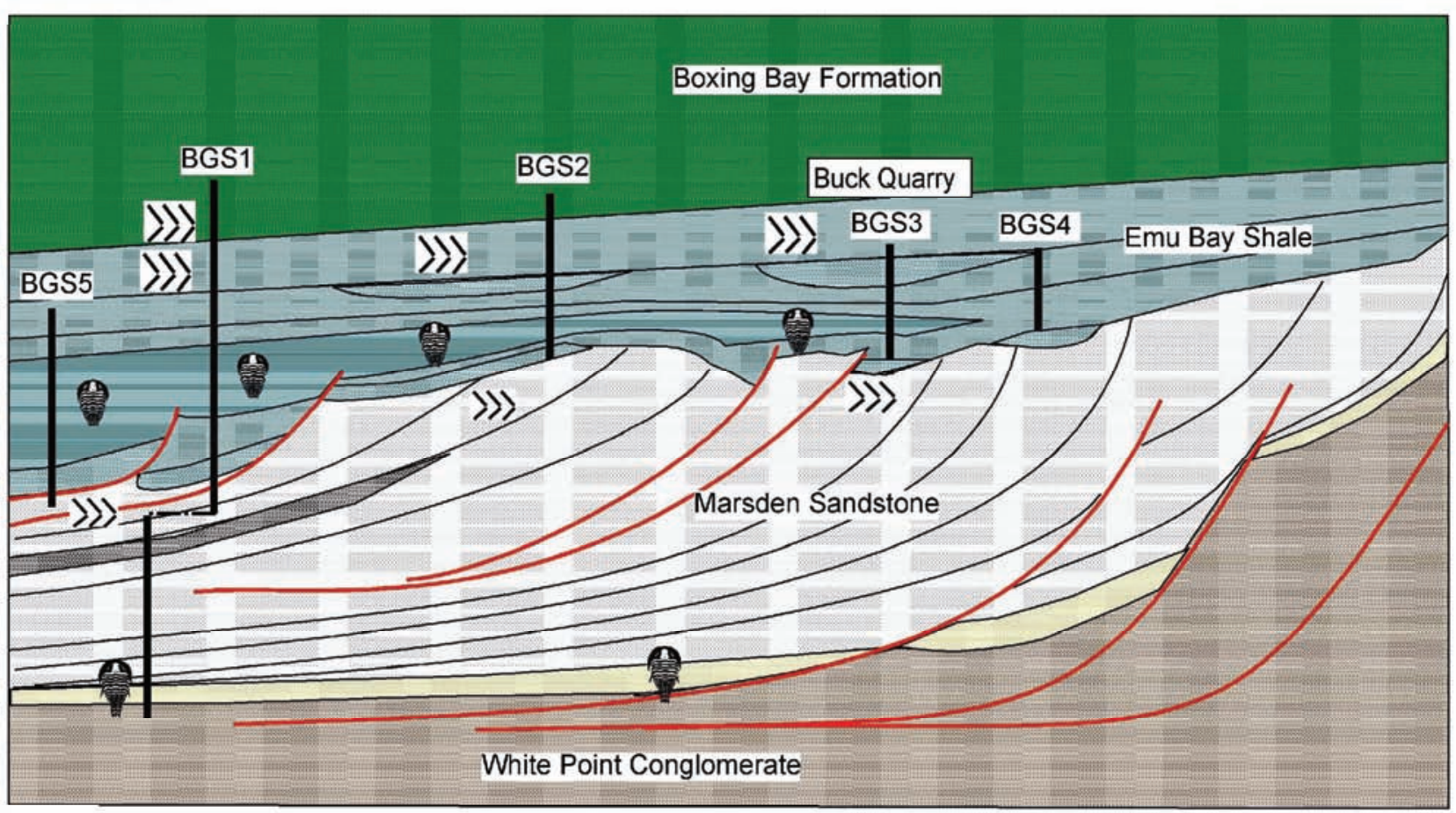

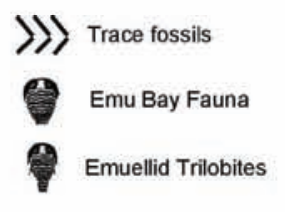

Legend
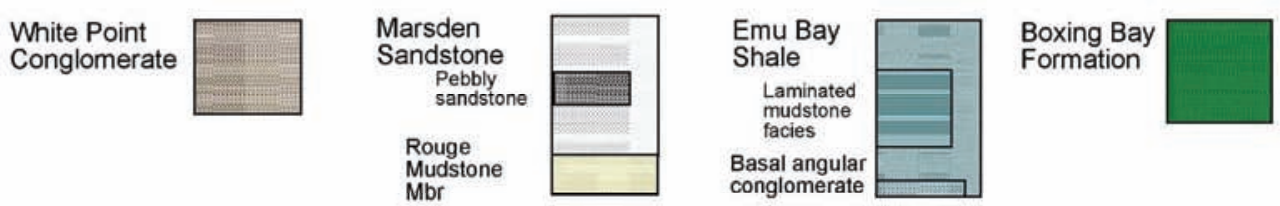

Figure 4 Schematic N-S cross-section through the Big Gully area (from Gehling et al., 2011). BGS, Big Gully Section.

Cruziana and Monomorphichnus occurring in fine sandstone towards the top of the unit. The Emu Bay Shale is overlain by the subtidal Boxing Bay Formation that comprises a red-brown feldspathic sandstone with abundant arthropod tracks.

\section{Fossil content of the Emu Bay Shale Lagerstätte}

The Emu Bay Shale Lagerstätte was first reported from coastal outcrops $3 \mathrm{~km} \mathrm{E}$ of Emu Bay by Daily (1956), with the first descriptions of soft-bodied taxa published by Glaessner (1979). Summaries are in Paterson and Jago (2006) and Paterson et al. (2008). Excavation at a new locality, Buck Quarry, several hundred metres inland commenced in 2007 (Paterson et al., 2008). This has yielded a greater variety of taxa than the coastal locality. At this new locality the fossil content of the Emu Bay Shale Lagerstätte is dominated by the trilobite Estaingia bilobata that makes up well over $75 \%$ of the biota. Redlichia takooensis is relatively common, but other trilobites are rare. Glaessner (1979) and García-Bellido et al. (2009) described species of the bivalved arthropods Isoxys and Tuzoia. Paterson et al. (2010), Edgecombe et al. (2011) and Paterson et al. (2012) described new taxa of nektaspid, megacheiran and other artiopodan arthropods, respectively. Investigation of other arthropods is continuing. Glaessner (1979) described the palaeoscolecid Palaeoscolex antiquus plus the enigmatic forms Vetustovermis planus and Myoscolex ateles. McHenry and Yates (1993) reported the Cambrian predator Anomalocaris. Anomalocaris briggsi was erected by Nedin (1995a) who left a second species under open nomenclature. Other fossils include sponges, chancelloriids, hyoliths, brachiopods, a vetulicolian, an Odontogriphus-like organism plus several other enigmatic forms. The oldest, well preserved, complex, arthropod eyes, including those of Anomalocaris, have been reported from this biota (Lee et al., 2011; Paterson et al., 2011).

\section{Acknowledgements}

Property owners Paul and Carmen Buck, Ian and Di Fargher, Warren and Barbara Fargher, Graham Ragless are thanked for permitting access to their properties. We thank our colleagues in South Australian Cambrian research: Greg Edgecombe, Diego GarcíaBellido, Colin Gatehouse, Lars Holmer, Mike Lee, Christian Skovsted and Timothy Topper. Peter Jell and Elinor Alexander are thanked for constructive reviews. Elinor Alexander, Elaine Appelbee and Carice Holland are thanked for organising the drafting of Figures 1 and 2.

\section{References}

Bengtson, S., Conway Morris, S., Cooper, B.J., Jell, P.A. and Runnegar, B.N., 1990, Early Cambrian shelly fossils from South Australia: Association 
of Australasian Palaeontologists, Memoirs, v. 9, pp. 1-364.

Bischoff, G.C.O., 1976, Dailyatia, a new genus of the Tommotiidae from Cambrian strata of SE Australia (Crustacea, Cirripedia): Senckenbergiana lethaia, v. 57, pp. 1-33.

Brock, G.A. and Cooper, B.J., 1993, Shelly fossils from the Early Cambrian (Toyonian) Wirrealpa, Aroona Creek and Ramsay Limestones of South Australia: Journal of Paleontology, v. 67, pp. 758-787.

Brock, G.A., Engelbretsen, M.J., Jago, J.B., Kruse, P.D., Laurie, J.R., Shergold, J.H., Shi, G.R. and Sorauf, J.E., 2000, Palaeobiogeographic affinities of Australian Cambrian faunas: Association of Australasian Palaeontologists, Memoirs, v. 23, pp. 1-61.

Clarke, J.D.A., 1990, Slope facies deposition and diagenesis of the Early Cambrian Parara Limestone, Wilkawillina Gorge, South Australia: Geological Society of Australia, Special Publication, v. 16, pp. 230-246.

Daily, B., 1956, The Cambrian in South Australia, in Rodgers, J. (ed), El Sistema Cambrico, su Paleogeografia y el Problema de su base: $20^{\text {th }}$ International Geological Congress, Mexico, v. 2, pp. 91-147.

Daily, B., 1976, The Cambrian of the Flinders Ranges: $25^{\text {th }}$ International Geological Congress, Excursion Guide 33A, pp. 15-19.

Daily, B. and Forbes, B.G., 1969, Notes on the Proterozoic and Cambrian, southern and central Flinders Ranges, South Australia, in Daily, B. (ed), Geological Excursions Handbook: ANZAAS, Section 3, Adelaide, pp. 49-54.

Daily, B., Milnes, A.R., Twidale, C.R. and Bourne, J.R., 1979, Geology and Geomorphology, in Tyler, M.J., Twidale, C.R. and Ling, J.K. (eds), Natural History of Kangaroo Island: Royal Society of South Australia, Adelaide, pp. 1-38.

Daily, B., Moore, P.S. and Rust, B.R., 1980, Terrestrial-marine transition in the Cambrian rocks of Kangaroo Island, South Australia: Sedimentology, v. 27, pp. 279-299.

Edgecombe, G.D., García-Bellido, D.C. and Paterson, J.R., 2011, A new leanchoiliid megacheiran arthropod from the lower Cambrian Emu Bay Shale, South Australia: Acta Palaeontologica Polonica, v. 56, pp. 385400 .

Flöttman, T., Haines, P., Jago, J., James, P., Belperio, A. and Gum, J. 1998, Formation and reactivation of the Cambrian Kanmantoo Trough, SE Australia: implications for early Palaeozoic tectonics at eastern Gondwana's plate margin: Geological Society of London, Journal, v. 155, pp. 525-539.

Foden, J., Elburg, M., Dougherty-Page, J. and Burtt, A., 2006, The timing and duration of the Delamerian Orogeny: Correlation with the Ross Orogen and implications for Gondwana reassembly: Journal of Geology, v. 114 , pp. 189-210.

Fuller, M.K. and Jenkins, R.J.F., 2007, Reef corals from the Lower Cambrian of the Flinders Ranges, South Australia: Palaeontology, v. 50, pp. 961980 .

García-Bellido, D.C., Paterson, J.R., Edgecombe, G.D., Jago, J.B., Gehling, J.G. and Lee, M.S.Y., 2009, The bivalved arthropods Isoxys and Tuzoia with soft-part preservation from the lower Cambrian Emu Bay Shale Lagerstätte (Kangaroo Island, Australia): Palaeontology, v. 52, pp. 12211241

Gehling, J.G., Jago, J.B., Paterson, J.R., García-Bellido, D.C. and Edgecombe, G.D., 2011, The geological context of the lower Cambrian (Series 2) Emu Bay Shale Lagerstätte and adjacent stratigraphic units, Kangaroo Island, South Australia: Australian Journal of Earth Sciences, v. 58, pp. 243-257.

Glaessner, M.F., 1979, Lower Cambrian Crustacea and annelid worms from Kangaroo Island, South Australia: Alcheringa, v. 3, pp. 21-31.

Gravestock, D.I., 1984, Archaeocyatha from lower parts of the Lower Cambrian carbonate sequence in South Australia: Association of Australasian Palaeontologists, Memoirs, v. 3, pp. 1-139.

Gravestock, D.I., 1995, Early and middle Palaeozoic, in Drexel, J. F. and Preiss, W.V. (eds), The Geology of South Australia, Volume 2, The Phanerozoic: South Australia Geological Survey, Bulletin, v. 54, pp. 361

Gravestock, D.I. and Shergold, J.H., 2001, Australian Early and Middle
Cambrian sequence stratigraphy with implications for species diversity and correlation, in Zhuravlev, A. Y. and Riding, R. (eds), The ecology of the Cambrian radiation: Columbia University Press, pp. 105-136.

Gravestock, D.I., Alexander, E.M., Demidenko, Y.E., Esakova, N.V., Holmer, L.E., Jago, J.B., Lin T.R., Melnikova, L.M., Parkhaev, P.Y., Rozanov, A.Y., Ushatiskaya, G.T., Zang W.L., Zhegallo, E.A. and Zhuravlev., A.Y., 2001, The Cambrian biostratigraphy of the Stansbury Basin, South Australia. Moscow: Palaeontological Institute of the Russian Academy of Sciences, Transactions, v. 282, pp. 1-344.

Hall, P.A., McKirdy, D.M., Halverson, G.P., Jago, J.B. and Gehling, J.G., 2011, Biomarker and isotopic signatures of an early Cambrian Lagerstätte in the Stansbury Basin, South Australia: Organic Geochemistry, v. 42, pp. 1324-1330.

Haslett, P.G., 1975, The Woodendinna Dolomite and Wirrapowie Limestone - two new Lower Cambrian formations, Flinders Ranges, South Australia: Royal Society of South Australia, Transactions, v. 99, pp. 211-220.

Jago, J.B. and Zang, W.L. (eds) 2006, South Australia 2006. XI International Conference of the Cambrian Stage Subdivision Working Group. Field Guide: Geological Society of Australia, South Australian Division, Adelaide, pp. 1-59.

Jago, J.B., Zang, W.L., Sun, X.W., Brock, G.A., Paterson, J.R. and Skovsted, C.R., 2006, A review of the Cambrian biostratigraphy of South Australia: Palaeoworld, v. 15, pp. 406-423.

Jago, J.B., Gatehouse, C.G., Powell, C. McA., Casey, T. and Alexander, E.M., 2010, The Dawson Hill member of the Grindstone Range Sandstone in the Flinders Ranges, South Australia: Royal Society of South Australia, Transactions, v. 134, pp. 115-124.

James, N.P. and Gravestock, D.I., 1990, Lower Cambrian shelf and shelf margin buildups, Flinders Ranges, South Australia: Sedimentology, v. 37, pp. $455-480$.

Kruse, P.D., 1991, Cyanobacterial-archaeocyathan-radiocyathan bioherms in the Wirrealpa Limestone of South Australia: Canadian Journal of Earth Sciences, v. 28, pp. 601-615.

Kruse, P.D., Jago, J.B. and Laurie, J.R., 2009, Recent developments in Australian Cambrian biostratigraphy: Journal of Stratigraphy, v. 33, pp. 231-241.

Lee, M.S.Y., Jago, J.B., García-Bellido, D.C., Edgecombe, G.D., Gehling, J.G. and Paterson, J.R., 2011, Modern optics in exceptionally preserved eyes of Early Cambrian arthropods from Australia: Nature, v. 474, pp. 631-634.

McHenry, B. and Yates, A., 1993, First report of the enigmatic metazoan Anomalocaris from the Southern Hemisphere and a trilobite with preserved appendages from the Early Cambrian of Kangaroo Island, South Australia: South Australian Museum, Records, v. 26, pp. 77-86.

McKirdy, D.M.., Hall, P.A., Nedin, C., Halverson, G.P., Michaelsen, B.H., Jago, J.B., Gehling, J.G and Jenkins, R.J.F., 2011, Paleoredox status and thermal alteration of the lower Cambrian (Series 2) Emu Bay Shale Lagerstätte, South Australia: Australian Journal of Earth Sciences, v. 58, pp. 259-272.

Moore, P.S., 1980, Stratigraphy and depositional environments of the Billy Creek Formation (Cambrian), east of the Flinders Ranges, South Australia: Royal Society of South Australia, Transactions, v. 104, pp. 117-132.

Mount, J.F. and McDonald, C., 1992, Influence of changes in climate, sea level and depositional systems in the fossil record of the Neoproterozoic - Early Cambrian metazoan radiation, Australia: Geology, v. 20, pp. 10311034.

Nedin, C., 1995a, The Emu Bay Shale, a Lower Cambrian fossil Lagerstätten, Kangaroo Island, South Australia: Association Australasian Palaeontologists, Memoirs, v. 18, pp. 31-40.

Nedin, C., 1995b, The palaeontology and palaeoenvironment of the Early Cambrian Emu Bay Shale, Kangaroo Island, South Australia: PhD thesis, University of Adelaide (unpublished).

Paterson, J.R. and Brock, G.A., 2007, Early Cambrian trilobites from Angorichina, Flinders Ranges, South Australia, with a new assemblage from the Pararaia bunyerooensis Zone: Journal of Paleontology, v. 81, pp. 116-142. 
Paterson, J.R. and Jago, J.B., 2006, New trilobites from the Lower Cambrian Emu Bay Shale Lagerstätte at Big Gully, Kangaroo Island, Australia: Association of Australasian Palaeontologists, Memoirs, v. 32, pp. 4357.

Paterson, J.R., Jago, J.B., Brock, G.A. and Gehling, J.G., 2007a, Taphonomy and palaeoecology of the emuellid trilobite Balcoracania dailyi (early Cambrian, South Australia): Palaeogeography, Palaeoclimatology, Palaeoecology, v. 249, pp. 302-321.

Paterson, J.R., Skovsted, C.B., Brock, G.A. and Jago, J.B., 2007b, An early Cambrian faunule from the Koolywurtie Limestone Member (Parara Limestone), Yorke Peninsula, South Australia: Australasian Association of Palaeontologists, Memoirs, v. 34, pp. 131-146.

Paterson, J.R., Jago, J.B., Gehling, J.G., García-Bellido, D.C., Edgecombe, G.D. and Lee, M.S.Y., 2008, Early Cambrian arthropods from the Emu Bay Shale Lagerstätte, South Australia, in Rábano, I., Gozalo, R. and García-Bellido, D. (eds), Advances in trilobite research. Cuadernos del Museo Geominero, 9, Instituto Geológico y Minero de Espana, Madrid, pp. 319-325.

Paterson, J.R., Edgecombe, G.D., Garcia-Bellido, D.C., Jago, J.B. and Gehling, J.G., 2010, Nektaspid arthropods from the lower Cambrian Emu Bay Shale Lagerstätte, South Australia, with a reassessment of lamellipedian relationships: Palaeontology, v. 53, pp. 377-402.

Paterson, J.R., Garcia-Bellido, D.C., Lee, M.S.Y., Brock, G.A., Jago, J.B. and Edgecombe, G.D., 2011. Acute vision in the giant Cambrian predator Anomalocaris and the origin of compound eyes. Nature, v. 480, pp. 237-240.

Paterson, J.R., García-Bellido, D.C. and Edgecombe, G.D., 2012, New artiopodan arthropods from the early Cambrian Emu Bay Shale Konservat-Lagerstätte of South Australia: Journal of Paleontology, v. 86, pp. 340-357.

Reilly, M.R. and Lang, S.C., 2003, A ponded basin floor fan outcrop analogue: Bunkers Sandstone, northern Flinders Ranges, Australia: APPEA Journal, v. 43, pp. 537-553.

Skovsted, C.B., Brock, G.A. and Paterson, J.R., 2006, Bivalved arthropods from the Lower Cambrian Mernmerna Formation, Arrowie Basin, South Australia and their implications for identification of "small shelly fossils": Association of Australasian Palaeontologists, Memoirs, v. 32, pp. 7-41.

Skovsted, C.B., Brock, G.A., Paterson, J.R., Holmer, L.E. and Budd, G., 2008, The scleritome of Eccentrotheca from the Lower Cambrian of South Australia: Lophophorate affinities and implications for tommotiid phylogeny: Geology, v. 36, pp. 171-174.

Skovsted, C.B., Balthasar, U., Brock, G.A. and Paterson, J.R., 2009a, The tommotiid Camenella reticulosa from the early Cambrian of South

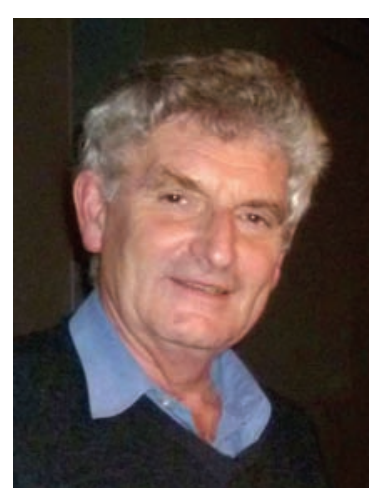

Jim Jago obtained his BSc from the University of Tasmania (1966) and his PhD from the University of Adelaide (1973). He joined the South Australian Institute of Technology in 1971 and has continued at SAIT/University of South Australia. He is currently Adjunct Associate Professor within the School of Natural and Built Environments, University of South Australia. His main research interests are in Cambrian biostratigraphy, particularly of Tasmania, South Australia and Antarctica.
Australia: Morphology, scleritome reconstruction, and phylogeny: Acta Palaeontologica Polonica, v. 54, pp. 525-540.

Skovsted, C.B., Holmer, L.E., Larsson, C.M., Högström, A.E.S., Brock, G.A., Topper, T.P., Balthasar, U., Petterson Stolk, S. and Paterson, J.R., 2009b, The scleritome of Paterimitra: an Early Cambrian stem group brachiopod from South Australia: Royal Society of London, Proceedings B, v. 276, pp. 1651-1656.

Skovsted, C.B., Brock, G.A., Topper, T.P., Paterson, J.R. and Holmer, L.E., 2011, Scleritome construction, biofacies, biostratigraphy and systematics of the tommotiid Eccentrotheca helenia sp. nov. from the early Cambrian of South Australia: Palaeontology, v. 54, pp. 253-286.

Topper, T.P., Skovsted, C.B., Brock, G.A. and Paterson, J.R., 2007, New bradoriids from the lower Cambrian Mernmerna Formation, South Australia: systematics, biostratigraphy and biogeography: Association of Australasian Palaeontologists, Memoirs, v. 33, pp. 67-100.

Topper, T.P., Brock, G.A. Skovsted, C.B. and Paterson, J.R., 2009, Shelly fossils from the lower Cambrian Pararaia bunyerooensis Zone, South Australia: Association of Australasian Palaeontologists, Memoirs, v. 37, pp. $199-246$.

Topper, T.P., Skovsted, C.B., Brock, G.A. and Paterson, J.R., 2011, The oldest bivalved arthropods from the early Cambrian of East Gondwana: Systematics, biostratigraphy and biogeography: Gondwana Research, v. 19, pp. 310-326.

Youngs, B.C., 1977. The sedimentology of the Cambrian Wirrealpa and Aroona Creek Limestones: Geological Survey of South Australia, Bulletin, v. 47.

Zang, W. L., Jago, J. B., Alexander, E. M. and Paraschivoiu, E., 2004, A review of basin evolution, sequence analysis and petroleum potential of the frontier Arrowie Basin, South Australia, in Boult, P.J., Johns, D.R. and Lang, S.C. (eds), Eastern Australian Basins Symposium II: Petroleum Exploration Society of Australia, Special Publication, pp. 243-256.

Zang, W.L., Jago, J.B. and Alexander, E.M., 2006, An outline of the Cambrian stratigraphy of South Australia, in Jago, J.B. and Zang, W.L. (eds), South Australia 2006. XI International Conference of the Cambrian Stage Subdivision Working Group. Field Guide: Geological Society of Australia, South Australian, Division, Adelaide, pp. 26-31.

Zang, W.L., Moczydlowska, M. and Jago, J.B., 2007, Lower Cambrian acritarch assemblage zones in South Australia and global correlation: Association of Australasian Palaeontologists, Memoirs, v. 33, pp. 141177.

Zhuravlev, A. Y and Gravestock, D. I., 1994, Archaeocyaths from Yorke Peninsula, South Australia and archaeocyathan Early Cambrian zonation: Alcheringa, v. 18, pp. 1-54.

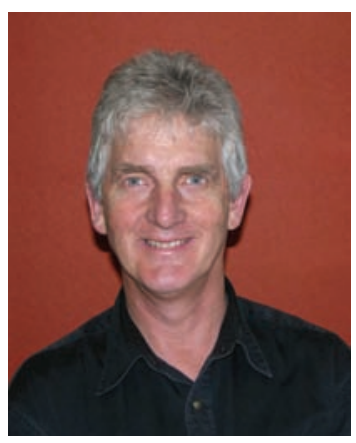

Jim Gehling is a Senior Research Scientist in Paleontology in the Earth Sciences Division of the South Australian Museum. He graduated from the University of Adelaide (BSC Hons and $M S c$ ), and from University of California, Los Angeles (PhD). His current research is on the paleobiology and paleoenvironments of fossils of the Ediacara biota from the Flinders Ranges and the Early Cambrian Emu Bay Shale biota of Kangaroo Island, South Australia. 


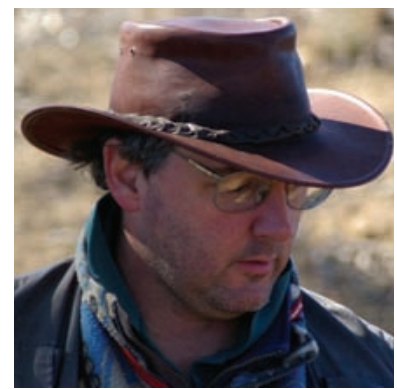

Associate Professor Glenn A. Brock leads a vibrant paleobiology research lab in the Department of Biological Sciences at Macquarie University, Sydney, Australia where his research activities focus on elucidating the evolution, phylogeny, biodiversity, ecology and biostratigraphy of the earliest (stem group) bilaterian animals that arose during the Cambrian explosion.

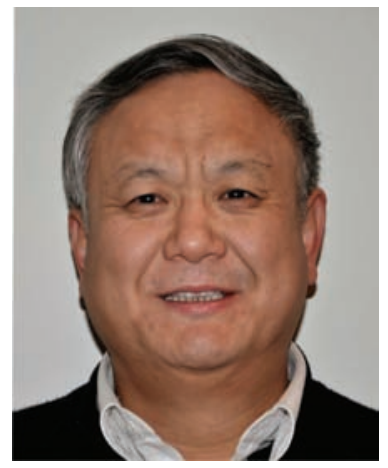

Wenlong Zang, graduated with a BSc (Hons) from the Beijing University and a PhD from the Australian National University in 1989. He then undertook studies of the Amadeus and Georgina basins with the Bureau of Mineral Resources before joining the Department of Mines and Energy, South Australia in 1991. His interests involve the studies of acritarch biostratigraphy, sequence stratigraphy, mapping and economic potential, including mineral and petroleum prospectivity in Australia and China.

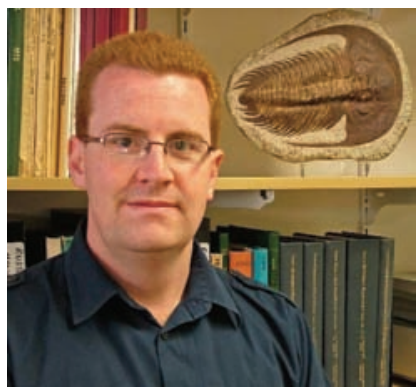

John R. Paterson is a Senior Lecturer and Convenor of Earth Sciences at the University of New England, Armidale, Australia. His research focuses on Cambrian faunas (especially arthropods) of Australia, particularly the Emu Bay Shale Konservat-Lagerstätte on Kangaroo Island. He is currently a member of the International Subcommission on Cambrian Stratigraphy Working Groups for Stages 3 and 4. 